\title{
Effects of Demographic and Educational Changes on the Labor Markets of Brazil and Mexico
}

\author{
Ernesto F. L. Amaral, Bernardo L. Queiroz, and Júlia A. Calazans
}

RAND Labor \& Population

WR-1089

February 2015

This paper series made possible by the NIA funded RAND Center for the Study of Aging (P3OAG01 2815) and the NICHD funded RAND Population Research Center (R24HD050906).

This paper is part of the research project "Demographic transition, labor market, and concentration of highly skilled workers in developing countries" funded by the Minas Gerais Research Support Foundation, Brazil

(FAPEMIG) (CSA 01802-13 APQ) and the Brazilian Ministry of Science, Technology, and Innovation (CNPq/MCTI) (474156/2013-3).

RAND working papers are intended to share researchers' latest findings and to solicit informal peer review. They have been approved for circulation by RAND Labor and Population but have not been formally edited or peer reviewed. Unless otherwise indicated, working papers can be quoted and cited without permission of the author, provided the source is clearly referred to as a working paper. RAND's publications do not necessarily reflect the opinions of its research clients and sponsors. RAND® is a registered trademark. 


\title{
Effects of demographic and educational changes on the labor markets of Brazil and Mexico
}

\author{
Ernesto F. L. Amaral \\ RAND Corporation \\ eamaral@rand.org
}

Bernardo L. Queiroz

Universidade Federal de Minas Gerais, Brazil

lanza@cedeplar.ufmg.br

Júlia A. Calazans

Universidade Federal de Minas Gerais, Brazil

jucalanzans@cedeplar.ufmg.br

\begin{abstract}
This paper estimates the impact of demographic and educational changes on the earnings and returns to schooling of workers in Brazil and Mexico. Our analysis takes into account demographic, educational and economic variations within each country over time, using Censuses microdata from Brazil and Mexico. Results suggest that demographic and educational transitions generate impact on earnings and on returns to education. The proportion of people in age-education groups tends to have a negative impact on earnings. These impacts are more detrimental among age-education groups with higher education, but they are having less of a negative effect over time. We also find that the concentration of skilled labor has positive impacts on the rates of returns to education and that they are greater than those observed in more developed countries. Moreover, in Brazil and Mexico, these effects are observed throughout the income distribution, contrary to what is observed in studies for the United States.
\end{abstract}

\section{Keywords}

Demographic transition. Education transition. Cohort size. Earnings. Labor Markets. Brazil. Mexico.

\section{Acknowledgements}

This manuscript is part of the research project "Demographic transition, labor market, and concentration of highly skilled workers in developing countries" funded by the Minas Gerais Research Support Foundation, Brazil (FAPEMIG) (CSA 01802-13 APQ) and the Brazilian Ministry of Science, Technology, and Innovation (CNPq/MCTI) (474156/2013-3). 


\section{Introduction}

The objective of this paper is to estimate the impact of demographic and educational changes on the earnings of workers in the two largest Latin American countries (Brazil and Mexico). Furthermore, we analyze the economic consequences of individuals with higher educational attainment (human capital) being concentrated within certain locations on the returns to schooling. The first exercise studies the impacts of the composition of the workforce by age and education on the average earnings of workers. The second exercise looks on how the concentration of skilled workers impacts the returns to schooling across regions of Brazil and Mexico. These two countries have very similar features and are passing through a rapid process of demographic and educational changes with large regional and social inequalities. ${ }^{1-11}$ Our analysis takes into account demographic, educational and economic variations within each country and their regions over time. The study of wage differentials and the analysis of the effects of human capital concentration in developing countries are both important subjects to explore, since they are marked by larger economic differentials than developed countries.

The central advantage is that the concentration of well-educated people benefits everyone else in the population, as well as generates greater knowledge and economic dynamism. In the United States, the concentration of skilled people in some regions has a positive impact on productive gains, which further increases the concentration of qualified people in these areas. ${ }^{12}$ The greatest concentration of skilled people in specific locations occurred in the 1980s and 1990s, leading to an increase in the wages of all workers. ${ }^{13-16}$ The larger proportion of people with higher educational attainment benefits the population as a whole, as the result of a spillover effect. ${ }^{16,17}$ Thus, there is a positive impact of population concentration on individual incomes. ${ }^{13-15}$ Other studies indicate that there are positive effects on the economic dynamism of American cities resulting from the concentration of skilled workers. ${ }^{18,19}$

There are numerous studies evaluating wage differentials and income concentration in several developing countries. However, there are few comparative studies of the dynamics that have recently been affecting local labor markets. Studies analyzed the concentration of human capital in Brazil ${ }^{20}$, but they did not investigate the reasons or the implications of this concentration. Other studies emphasized positive effects of the concentration of skilled workers in the Brazilian labor market. ${ }^{21}$ However, variations in cohort size across municipalities in Brazil led to impacts on workers' earnings. ${ }^{22-26}$ More specifically, higher proportions of the population in ageeducation groups decrease the income of these groups. These effects are larger for groups with higher educational attainment, but with declining effects over time. Thus, the concentration of skilled workers in specific locations can generate benefits for some groups, but can produce negative results for other groups.

This paper is part of a broader discussion of regional differences in income and economic growth. The issue of inter-regional income differentials has motivated numerous studies about various countries, in order to explain 
the existence and persistence of inequalities over time. However, studies about the concentration of skilled labor in developing countries and comparative analyzes are not regularly performed. ${ }^{20,22,27}$ The concentration of human capital in certain locations can result in numerous benefits for the local economy and boost economic growth. However, there is also potential for a negative impact on earnings. Earnings of male workers appear to be significantly influenced by the age-education composition of the workforce, i.e., large cohorts do depress earnings. ${ }^{13-15,22,28-39}$ This concentration of workers and variation in cohort size might also affect the level of

unemployment. ${ }^{28,30}$ However, at the same time other studies show that the concentration of high-skilled workers in some parts of the country can have positive impacts on the returns to education, known as social returns to education. $^{12,16}$

These changes in the labor markets have important implications to public policies and are even more relevant in the context of rapid demographic changes and population aging. We argue that positive spillover effects from the concentration of more skilled workers and changes in the age-educational composition of the labor force might impact the dynamic of local labor markets by creating better jobs and changing the status of a longer working life. In terms of policies, investments in education and attracting technological companies might be the best predictor of a dynamic economy in the near future as opposed to a traditional industrial sector. These investments are already experienced by mature economies, such as the Unite States, but one can expect that large developing economies would follow similar patterns.

\section{Data and methods}

We perform two exercises to investigate the impacts of demographic and educational changes in the Brazilian and Mexican labor markets. The first exercise studies the impacts of the composition of the workforce by age and education on the average earnings of workers. This analysis uses local-level data to construct age-education cells and follows their changes over time. The second study uses individual data to investigate how the concentration of skilled workers impacts the returns to schooling across regions of Brazil and Mexico. In the following sub-sections we present detailed information on the construction of the database and methods applied to investigate the two questions. We use microdata from the Brazilian and Mexican Demographic Censuses to estimate the impact of population flows on the earnings of male workers at the local level over time. Brazilian (1970-2010) and Mexican (1960-2010) data were obtained from from IPUMS-International, Minnesota Population Center, University of Minnesota.

We categorized information on age into four groups: youths (15-24 years-of-age); young adults (25-34 years-ofage); experienced adults (35-49 years-of-age); and older adults (50-64 years-of-age). In the analysis of the returns to education, we considered only males aged 15 to 60 who were in the labor force and perform the 
analysis across all ages. We also perform some robustness checks using data for those in the prime-age group, between 30 and 50 years old.

The level of education was classified into four groups using information on completed years of schooling and taking into account the specificities of the school systems in Brazil and Mexico. For Brazil, the education groups are: (a) incomplete first phase of elementary school (0-3 years of schooling); (b) complete first phase of elementary school (4 years of schooling) or second phase of elementary school (5-8 years of schooling); (c) secondary school (9-11 years of schooling); and (d) at least some college (12+ years of schooling). For Mexico, the education groups are: (a) no education (0 years of schooling); (b) primary school (1-6 years of schooling); (c) lower secondary ("escuela secundaria") (7-9 years of schooling) or secondary school ("escuela preparatoria o bachillerato") (10-12 years of schooling); and (d) at least some college ("nivel universitario") (13+ years of schooling).

\subsection{Demographic changes and earnings}

We aggregate Census microdata by year, area, and age-education group. In relation to the geographical areas considered for this study, the 502 Brazilian micro-regions (groups of municipalities) have consistent boundaries over time. These 502 micro-regions differ from those defined by IBGE and available in the Census microdata, but closely approximate those that are defined in the 1991 Census. ${ }^{7}$ For Mexico, the geographical areas used for this study were 2,456 municipalities, from 1990 to 2010.. Mexican municipalities have consistent boundaries in our database only for these last three censuses. We also estimated models by the 32 Mexican states using all censuses, but due to the lack of data variation the results were not consistent (results not shown).

In order to measure the effect of demographic and educational transitions on earnings, the dependent variable is the natural logarithm of the mean monthly earnings for each year, area, and age-education group. In Brazil, information on earnings is based on primary occupation. In Mexico, information on earnings is based on earned income. For 1970, in both countries, information on earnings is based on total income, due to the lack of other available variables.

In Equation (1), $\log \left(Y_{\text {git }}\right)$ is the logarithm of wages. Sixteen indicators of age-education groups $(G)$ interacting with time $(\theta)$ are included in the model. The first age-education group interacting with time is the reference category. $G_{a e}$ is a set of age-education-group indicators (dichotomous variables) for each age group (a) and education group (e). The model considers 502 micro-regions in Brazil and 2,456 municipalities in Mexico (i), five Brazilian Censuses and three Mexican Censuses $(t), 16$ age-education groups $(g)$, and 2,510 (502*5) areatime-fixed effects in Brazil and 7,368 (2,456*3) area-time-fixed effects in Mexico $(\alpha)$. This estimation follows a standard Mincerian model ${ }^{40}$ : 
$\log \left(Y_{i g t}\right)=\beta_{0}+\left(\beta_{1} G_{12}+\ldots+\beta_{15} G_{44}\right) * \theta_{t}+\alpha_{i t}+\varepsilon_{g i t}$

Not only age and education have a significant impact on earnings, but also demographic and educational changes generate variation in cohort size and, thus, influence various aspects of the labor market. As a strategy to estimate the impact of cohort size on earnings, the distribution of the male population in our 16 age-education groups $(X)$, interacted with time $(\theta)$, can be introduced as a set of variables. This exercise is similar to a study that estimated the impact of immigration on the U.S. labor market. ${ }^{41}$ In our case, instead of including the immigration supply in the estimations, we include information on the male population distributed into ageeducation groups, in order to verify its impacts on earnings:

$\log \left(Y_{i g t}\right)=\beta_{0}+\left(\beta_{1} G_{12}+\ldots+\beta_{15} G_{44}\right) * \theta_{t}+\left(\gamma_{1} X_{11}+\ldots+\gamma_{15} X_{44}\right) * \theta_{t}+\alpha_{i t}+\varepsilon_{g i t}$

Because Brazil was divided into 502 micro-regions, 16 age-education groups, and five censuses, the maximum possible number of observations for the regressions is 40,160 and the maximum number of groups (area-time fixed effects) is 2,510. However, only cells with at least 25 observations are included in the estimations, in order to minimize potential problems of heteroskedasticity. The maximum number of observations was reduced to 32,201 and the number of groups to 2,488. In Mexico, we used 2,456 municipalities, which would generate a maximum of $117,888\left(2,456 * 16^{*} 3\right)$ observations and 7,368 groups for the regressions. Due to our cell-size criteria, the number of observations was reduced to 82,604 and the number of groups to 7,259.

\subsection{Human capital concentration and returns to education}

We estimate the impact of the concentration of human capital and the private returns to education on earnings using regressions models. We use quantile regression models to allow for a more robust analysis to investigate these impacts across the income distribution. ${ }^{42,43}$ Our hypothesis is that the private and social returns to education vary due to the socioeconomic position of workers in their place of residence. Private returns to education are the individual gains for an additional year of schooling. ${ }^{40,44}$ The basic model on the social returns to education has the premise that personal investment in education and training create benefits for other agents in the economy, both to the more skilled and to less skilled. ${ }^{45}$ By investing in human capital individuals become more productive and relate to other employees in the workplace and elsewhere, due to their capacity of transmitting new knowledge and skills to others. ${ }^{45}$

The spatial distribution of human capital is associated with unobserved factors that can be correlated with the level of income, so the local educational level becomes endogenous in the model. ${ }^{13-15}$ To solve this problem, we estimate the concentration of highly skilled workers through an instrumental variable approach. We use 
education progression rates, age composition of the population, and local income level to estimate the concentration of educated workers in the current census. We use all instruments lagged to the previous census year. The proportion of high-skilled workers is defined by the following equation:

$P_{(t)}=\beta_{0}+\beta_{1} L_{1(t-n)}+\beta_{2} L_{2(t-n)}+\beta_{3} L_{3(t-n)}+e$,

where $P_{(t)}$ is the proportion of workers with high educational level (proportion of undergraduates) in time $t$ for each investigated area; $L_{1(t-n)}$ is the enrolment rate in high school in the previous census, $n$ years ago; $L_{2(t-n)}$ is the young-age-dependency ratio in the previous census; and $L_{3(t-n)}$ is the local average wage also in the previous census. The model to estimate social and private returns to education is:

$\log \left(Y_{\text {git }}\right)=\beta_{0}+\beta_{1} X+\varepsilon_{\text {git }}$

where $\log \left(Y_{\text {git }}\right)$ is the logarithm of individual earnings. The two main variables of interest are the proportion of workers with high educational level (estimated in Equation 3) and individual schooling (measured in years of education). The proportion of educated workers in the region captures the social returns to education, whereas the individual schooling captures private returns to education. We also add age and age-squared variables, because income varies with age and individuals have a return to experience. In the model, we also include variables to capture labor demand in the region and control for regional characteristics (region of the country and local unemployment rate). Municipality clusters adjusted the standard errors of these regression models. We also estimated Equation 4, using the original proportion of workers with high educational level, without the instruments from Equation 3 (results not shown). The results suggest that the impacts of concentration of human capital are much lower when we do not use instrumental variables, which would underestimate the results of our final models.

\section{Results}

\subsection{Demographic changes and earnings}

The estimation of an income equation is central to assess the impact of an aging population and educational changes on average income. This analysis seeks to establish whether changes in age and education structures influenced income in Brazil and Mexico. Before estimating the models, it is important to evaluate the distribution of the male population by year and age-education group in the countries (Tables 1 and 2). In general, the proportion of men with 0-3 years of education decreased between 1970 and 2010 in Brazil. For example, the proportion between 15-24 years of age with 0-3 years of education fell considerably from 20.00 percent in 1970 to 2.24 percent in 2010 in Brazil (Table 1). The same happened in Mexico for males with zero years of education and 15-24 years of age, with a decrease from 10.45 percent in 1960 to 0.44 percent in 2010 (Table 2). In 
addition, the proportion of those with least nine years of education (9-11 and 12+) in Brazil, as well as those with at least seven years of education (7-12 and 13+) in Mexico, increased during the period.

\section{>> Table $1<<<$ \\ $>>$ Table $2<<<$}

In Table 3 we present the coefficients and standard errors estimated with the fixed-effects model that replicates Mincer's model - Equation (1) - for Brazil. In this baseline model, we interact the indicator variables for ageeducation groups with each Census year. Thus, the coefficients in the first column are the impacts of age and education on earnings for 1970 (main effects). The interaction coefficients show the differential effects in the other years, in comparison to 1970, for each age-education group. The main effects indicate that, within each age category, earnings are higher for those people with more schooling. We also verify that within each education group, earnings are higher for older men. For instance, men ages 25-34 with zero to three years of schooling earned $1.35(\exp (0.302))$ times as much as men ages 15-24 with the same education (the reference category) in 1970. In order to verify these effects for the other years, the interaction terms have to be taken into account. In 2010, young men (25-34) with at least twelve years of schooling earned $3.93(\exp (2.386-1.018))$ times as much as the reference category. For Mexico (Table 4), the results follow the same pattern. For example, men ages 2534 with zero years of schooling earned $1.11(\exp (0.103))$ times as much as men ages 15-24 with the same education in 1990. In 2010, young men (25-34) with at least thirteen years of schooling earned $2.57(\exp (0.987-$ $0.0415)$ ) times as much as the reference category. The estimates are thus consistent with what we know about age-earnings profiles and the impact of education on them. Here as in the subsequent estimates, the coefficients of the fixed-effects model are highly significant statistically.

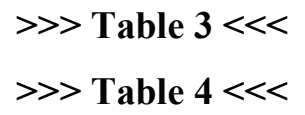

Table 5 (for Brazil) and Table 6 (for Mexico) illustrate the estimated coefficients and standard errors for the second model, which includes the proportion of males in each age-education group in the workforce as independent variables (cohort size, relative supply, labor supply, cell density, or own-quantity effects), and allows them to vary over time by interacting these proportions with Census years (time indicators). As in the previous model, the main effects show the impact on earnings in 1970 for Brazil and in 1990 for Mexico. These main effects have to be added to the interaction terms, in order to infer the trends.

$>>$ Table $5<<<$

$>>$ Table $6<<<$ 
In Brazil (Table 5), among all age-education groups (besides the last one), there are negative impacts of group size on earnings in the earliest period. The estimated coefficients in 1970 on the proportions of men in each ageeducation group generally indicate greater negative impacts for higher educated workers. These negative effects are offset by the positive interactions throughout time for more educated men. Indeed, by 2010 the positive coefficients on the interaction terms nearly offset the negative coefficients on the main effect terms, so that in the more educated groups the net impact on earnings of a change in the group proportions was much reduced. For men in the three age groups (15-24 years, 25-34 years, and 35-49 years) with 0-3 years of schooling (least educated), the group proportions have negative impacts on earnings in 1970 and they are becoming even more negative over time, as can be noticed by the negative coefficients of year interactions. In Mexico (Table 6), in the earliest period (1990), the greatest negative impacts of age-education-group proportions are observed for young men (25-34) with zero years of schooling and with 7-12 years of schooling. Proportions in age-education groups tend to have positive impacts on earnings among better-educated males (13+ years of schooling) in 1990. In 2010, the interaction terms are more negative for the better-educated groups (13+ years of schooling), which offset the coefficients from 1990.

In order to better understand the estimates, we calculate elasticities to demonstrate the impact of age-education proportions on earnings. Elasticity describes the relationship between two variables, and is defined as the ratio of the percentage change in a dependent variable to a percentage change in an independent variable. For example, an elasticity of -0.2 means that an increase by one percent in the independent variable provokes a fall of 0.2 percent in the dependent variable. Thus elasticity is a measure of responsiveness, and can be calculated for any two related variables. Table 7 (for Brazil) and Table 8 (for Mexico) present elasticities that were calculated as the product of age-education-proportions coefficients (Table 5 for Brazil and Table 6 for Mexico) and the distribution of men by age-education groups over time.. More specifically, the elasticities were estimated using this expression: (exp(coefficient of proportion in an age-education group*distribution of men by age-education group*0.01)-1)*100. For more recent years (interaction terms), the main effect coefficient (1970 in Brazil and 1990 in Mexico) was added to the interaction term for each Census, before multiplying by the distribution of men by age-education groups and year.

\section{$>>$ Table $7<<<$ \\ $>>$ Table $8<<<$}

Among the least-educated workers (0-3 years of schooling) in Brazil (Table 7), the elasticities are negative over time, without great variations for younger groups (15-24 and 25-34 age groups) across the Censuses. For older groups (35-49 and 50-34 age groups) within this education group, the negative impacts are not as strong in 2010 
compared to 1970. These results mean that the proportions of the least-educated men have negative impacts on their earnings (Table 5) in recent years, even with lower shares in the population. These estimates might suggest that the Brazilian labor market does not require as many low educated men in recent years, as it did in previous decades. Within each age group in 1970, Table 7 shows that elasticities are more negative among more educated males in the younger groups (15-24 and 25-34 age groups) and among less educated groups in the older group (35-49 and 50-64 age groups). In more recent years, the negative impacts lose magnitude. Exceptions are for older men (35-49 and 50-64 age groups) with 9-11 years of schooling, as well as for men ages 15-24 with 12+ years of schooling. For instance, an increase of ten percent in the number of men with 25-34 years and 12+ years of schooling would reduce their earnings by 1.3 percent $(-0.130)$ in 1970 and 0.4 percent in 2010 . We also observe this clear decline in the magnitude (toward zero) of these elasticities over time for those with 35-49 years and 12+ education. For men with 15-24 years and 9-11 years of schooling, there is a decline after 1980. For those with 50-64 years of age and 4-8 years of schooling, elasticities decline in 1991. An increase of ten percent in the number of people with 4-8 years of schooling and between 15 and 24 years of age would reduce their earnings by 2.3 percent $(-0.230)$ in 1970 and 1.1 percent in 2010. Among young men (25-34) with 4-8 years of schooling the impact on earnings declines from -2.0 percent in 1970 to -0.2 percent in 2010 for an increase of ten percent in the group. Among experienced adults (35-49) with 4-8 years of schooling, the elasticities become positive over time.

The Mexican estimates (Table 8) have smaller magnitudes than the Brazilian elasticities (Table 7). Elasticities in Mexico indicate that relative changes in labor supply (group proportions) have been having less of an impact on relative wages than they did at the start of our sample period. In 1990 among younger Mexicans (15-24 and 2534 age groups), the elasticities of those with 7-12 years of schooling present the strongest negative impacts on earnings. However, these negative impacts are much less pronounced in 2010. For older groups (35-49 and 5064 age groups) with zero years of schooling, the elasticities start positive in 1990 and become negative over

time. This may be indicative of low demand for labor without education. Among all groups in 2010, the only elasticities with negative impacts below -0.05 are for men ages 50-64 with 7-12 years of schooling $(-0.084)$. Some of the reasons for the small impact of the size of the highest educational attainment groups might be technological shifts and increasing demand for skilled labor.

\subsection{Human capital concentration and returns to education}

Tables 9 and 10 show the results of the impacts of human capital concentration on social and private returns to education. In the case of Brazil, being college graduates receive, on average, 160 percent higher income than those with less than primary education. We find similar result in Mexico, but the magnitude of the coefficient is much smaller. In both countries, as observed in the previous analysis, the returns to education have declined from 2000 to 2010. In Mexico, we find positive effects of education for all income levels. The results indicate 
that a one percent increase in the proportion of graduates is related to one percent increase in the wage levels. In Brazil, we also find positive impacts of the concentration, but the highest income groups benefit much more from the concentration than the lower income groups. The impact for workers in the wealthiest distribution (third quartile) is almost three times the impact on wages of the poorest workers (first quartile). In Mexico, the benefits are more similar across the income distribution. In 2010, for both countries, the benefits of concentration of human capital on earnings are higher in low-income groups than in higher income groups. For example, in Brazil an increase of one percent of workers with college degree in the third quartile is related to six percent increase in the average wage in 2000 and almost two percent increase in 2010. In Mexico, we observe an increase of five percent in 2000 and three percent in 2010.

\footnotetext{
$>>$ Table $9<<$

$>$ Table $10<<$

$>$ Figure $1<<$
}

Figure 1 illustrates the coefficients estimated for the social returns to education across income levels. The effect decreases for Mexico along the income distribution while for Brazil increases. The concentration of skilled workers in Brazil has a positive impact on individuals' earnings across the income distribution. One interesting and important result is that wealthier workers in Brazil benefit more from the concentration of skilled workers than those in the lowest quantile. The effects of concentration, however, have declined substantially over the recent period, which are related to the education progress that Brazil is observed in the recent periods. Compared to Mexico, we find that there is not much difference across income distribution, but poorer workers benefit little more than those in the top quintiles.

Our main hypothesis is that the labor force in Brazil is more evenly distributed in the territory compared to Mexico. As a result, in Brazil there is a "shortage" of skilled labor across the country. Workers are complementary in the labor market and generate positive externalities, especially among wealthier and more educated. We assume that complementary workers are those with different skills that create benefits to other individuals in the labor market or in the firm. They cannot easily substitute one another and to improve productivity it is important to have both workers in the same sector. In Mexico, as the markets are more concentrated, competition is greater. Mexican wealthier workers have a degree of substitution, that is, firms can easily find replacements for other workers what creates more completion for positions in the labor market and reduce the gains to education. As a consequence, the positive impacts of human capital concentration in Mexico are not as large as in Brazil, even though both countries are very unequal.

\section{Final considerations}


The advance of this study beyond the preceding literature is the inclusion of the age-education cell sizes (proportion of males in each age-education group, cohort size, relative supply, labor supply, cell density, or ownquantity effects) into the models. Estimations suggest that changes in the composition of the workforce influence the levels of earnings. The proportion of people in age-education groups tends to have a negative impact on earnings, with greater effects for higher educated groups. These results are consistent with previous studies, which indicate that age-education groups are not perfect substitutes, generating negative impacts of cohort size on workers' income. Even though there has been an increase in the demand for high-educated workers in Brazil and Mexico during recent decades, this variation was not significant enough to compensate for the increase in the supply of these better-qualified workers. For Mexico, we find a decrease in the proportion of the young population over time, as well as an increase in the proportion of people with higher levels of educational attainment, but with smaller magnitude compare to Brazil.

These results provide some insight that could assist in implementing policies that would decrease income inequality in the country. Since great variation in age and educational compositions across Brazilian and Mexican locations continue, the improvement of educational attainment in areas that still have large proportions of people with lower levels of schooling should become the focus of governmental policies. More specifically, the various levels of government should be concerned with the need to invest in secondary and university education, since the overall attainment level is still low in these countries.

We also find that the concentration of skilled workers, in recent years, is related to higher returns to schooling. This pattern is not surprising since regional differences for both countries are well known. The existence of these differences is sustained by labor market conditions, which are produced and appear to be maintained by the process of regional economic development. We found that there are social effects of human capital, i.e. locations with higher average human capital have higher salary levels and lower private rates of return to formal education. Results indicate positive and significant effect of the predicted proportion of undergraduates in the income level of workers across the income distribution. The concentration of human capital in specific regions generates benefits for the entire set of resident workers in the region. Even the less productive workers observe positive effects on their productivity and their wages. We argue that these effects are a result of the characteristics of the labor markets in Brazil and Mexico. Since the percentage of workers with higher education is small, the labor market faces two effects in opposite directions. On one side, there is a complementary effect, because more educated workers could benefit others with the same and lower levels of education by increasing overall productivity levels. On the other side, least-educated workers - a large share of labor force - compete with each other in the labor market and could be considered substitutes to each other, thus depressing wages. In the case of less developed economies, the negative effects are surpassing the positive ones. The results indicate 
that, especially for men ages 30-50 in Mexico and Brazil, the largest concentration of skilled labor have greater impacts on more educated workers across the income distribution (results not shown).

This paper finds that that the concentration of skilled workers is related to a higher average wage. However, we found that the poorest and most unequal countries (Brazil and Mexico) have a factor much stronger correlation than observed in more developed countries. ${ }^{13-15}$ The existence of these differences is sustained by the conditions of local labor markets, since in both countries we have more developed regions coexisting with regions still under development. The conditions of labor markets were produced and appear to be maintained by the regional economic development process. In summary, we found that there are social effects of human capital locations with higher average human capital have a higher level of wages and lower rates of private return to formal education. The concentration of human capital in regions generates benefits for the entire set of resident workers in the region even the least productive workers observe a positive effect on their productivity and their wages.

We believe that our results are relevant to a broad range of public policies, including labor market issues and education. In terms of inequality, the results indicate that the concentration of highly-skilled workers in some parts of the country might affect earnings and returns to education in those areas and tend to benefit more educated workers, what might lead to higher inequality levels. However, these effects have been declining over the last decades.

We also find that locations with larger concentration of skilled workers have more dynamic labor markets, which might experience positive trends in employment and earnings over the long run. As indicated by others ${ }^{12,20}$, cities where more educated workers concentrate tend to attract more educated and innovative workers. The concentration of more educated workers also have impacts on the structure of firms in each locality. One can expect that these "educated" cities will attract innovative companies and educated workers, which will result in more innovative companies, creating a virtuous cycle of economic growth and dynamism.

At the same time, this change in the labor market towards more technological jobs might have positive impacts on the labor supply of the elderly. In the last century, we observed an impressive reduction in the labor force participation of older workers. In part, the rise of public pension systems and increasing wealth of the elderly were important explanations for those changes. High attachment to the labor force was strongly related to physical demanding jobs - such as in agriculture and some industries. In recent years, working longer has become a high status characteristic, because the type of jobs hold by the elderly is changing from physical demanding to more intellectual demanding. 
Table 1. Male population distributed into particular age-education groups, as percentage shares, Brazil, 1970-2010.

\begin{tabular}{|c|c|c|c|c|c|}
\hline Age-education groups & 1970 & 1980 & 1991 & 2000 & 2010 \\
\hline $\begin{array}{l}15-24 \text { years; } \\
0-3 \text { years of schooling }\end{array}$ & 20.00 & 13.05 & 9.81 & 5.95 & 2.24 \\
\hline $\begin{array}{l}\text { 15-24 years; } \\
4-8 \text { years of schooling }\end{array}$ & 13.57 & 17.49 & 16.9 & 15.55 & 9.12 \\
\hline $\begin{array}{l}\text { 15-24 years; } \\
9-11 \text { years of schooling }\end{array}$ & 2.17 & 4.93 & 5.06 & 8.99 & 12.46 \\
\hline $\begin{array}{l}15-24 \text { years; } \\
12+\text { years of schooling }\end{array}$ & 0.57 & 1.04 & 0.91 & 1.25 & 3.04 \\
\hline $\begin{array}{l}25-34 \text { years; } \\
0-3 \text { years of schooling }\end{array}$ & 14.62 & 10.13 & 7.66 & 5.57 & 3.85 \\
\hline $\begin{array}{l}25-34 \text { years; } \\
4-8 \text { years of schooling }\end{array}$ & 7.07 & 10.22 & 11.57 & 10.87 & 7.65 \\
\hline $\begin{array}{l}25-34 \text { years; } \\
9-11 \text { years of schooling }\end{array}$ & 1.17 & 2.71 & 5.06 & 5.95 & 9.23 \\
\hline $\begin{array}{l}25-34 \text { years; } \\
12+\text { years of schooling }\end{array}$ & 0.83 & 2.07 & 2.34 & 2.17 & 4.59 \\
\hline $\begin{array}{l}35-49 \text { years; } \\
0-3 \text { years of schooling }\end{array}$ & 17.47 & 13.02 & 10.37 & 7.93 & 8.04 \\
\hline $\begin{array}{l}35-49 \text { years; } \\
4-8 \text { years of schooling }\end{array}$ & 6.81 & 8.60 & 10.41 & 12.12 & 9.56 \\
\hline $\begin{array}{l}35-49 \text { years; } \\
9-11 \text { years of schooling }\end{array}$ & 0.84 & 1.46 & 3.03 & 5.36 & 7.71 \\
\hline $\begin{array}{l}35-49 \text { years; } \\
12+\text { years of schooling }\end{array}$ & 0.75 & 1.36 & 2.51 & 3.10 & 4.08 \\
\hline $\begin{array}{l}50-64 \text { years; } \\
0-3 \text { years of schooling }\end{array}$ & 10.42 & 8.69 & 7.86 & 6.76 & 8.44 \\
\hline $\begin{array}{l}50-64 \text { years; } \\
4-8 \text { years of schooling }\end{array}$ & 3.07 & 4.17 & 4.79 & 5.60 & 3.94 \\
\hline $\begin{array}{l}50-64 \text { years; } \\
9-11 \text { years of schooling }\end{array}$ & 0.28 & 0.53 & 0.91 & 1.51 & 3.72 \\
\hline $\begin{array}{l}50-64 \text { years; } \\
12+\text { years of schooling }\end{array}$ & 0.35 & 0.52 & 0.81 & 1.33 & 2.34 \\
\hline Total & 100.00 & 100.00 & 100.00 & 100.00 & 100.00 \\
\hline Sample size (n) & $6,772,670$ & $7,895,865$ & $4,992,270$ & $6,287,104$ & $6,721,044$ \\
\hline Population size (N) & $25,760,594$ & $31,848,780$ & $43,434,534$ & $53,177,963$ & $62,707,571$ \\
\hline
\end{tabular}

Sources: 1970, 1980, 1991, 2000, and 2010 Brazilian Demographic Censuses (Brazilian Institute of Geography and Statistics - IBGE). 
Table 2. Male population distributed into particular age-education groups, as percentage shares, Mexico, 1960-2010.

\begin{tabular}{|c|c|c|c|c|c|}
\hline Age-education groups & 1960 & 1970 & 1990 & 2000 & 2010 \\
\hline $\begin{array}{l}15-24 \text { years; } \\
0 \text { years of schooling }\end{array}$ & 10.45 & 6.81 & 1.90 & 0.94 & 0.44 \\
\hline $\begin{array}{l}15-24 \text { years; } \\
1-6 \text { years of schooling }\end{array}$ & 21.49 & 21.50 & 12.20 & 8.78 & 4.28 \\
\hline $\begin{array}{l}15-24 \text { years; } \\
7-12 \text { years of schooling }\end{array}$ & 3.73 & 7.60 & 21.15 & 20.96 & 21.36 \\
\hline $\begin{array}{l}15-24 \text { years; } \\
13+\text { years of schooling }\end{array}$ & 0.39 & 1.23 & 2.69 & 2.84 & 3.81 \\
\hline $\begin{array}{l}25-34 \text { years; } \\
0 \text { years of schooling }\end{array}$ & 8.12 & 6.05 & 2.00 & 0.89 & 0.66 \\
\hline $\begin{array}{l}25-34 \text { years; } \\
1-6 \text { years of schooling }\end{array}$ & 14.63 & 14.64 & 10.29 & 7.79 & 5.27 \\
\hline $\begin{array}{l}25-34 \text { years; } \\
7-12 \text { years of schooling }\end{array}$ & 1.54 & 2.23 & 8.61 & 13.09 & 12.19 \\
\hline $\begin{array}{l}25-34 \text { years; } \\
13+\text { years of schooling }\end{array}$ & 0.53 & 1.30 & 4.24 & 4.28 & 5.37 \\
\hline $\begin{array}{l}35-49 \text { years; } \\
0 \text { years of schooling }\end{array}$ & 8.98 & 8.01 & 3.69 & 1.70 & 1.25 \\
\hline $\begin{array}{l}35-49 \text { years; } \\
1-6 \text { years of schooling }\end{array}$ & 14.08 & 14.85 & 12.72 & 11.32 & 8.54 \\
\hline $\begin{array}{l}35-49 \text { years; } \\
7-12 \text { years of schooling }\end{array}$ & 1.24 & 1.75 & 4.74 & 8.61 & 13.68 \\
\hline $\begin{array}{l}35-49 \text { years; } \\
13+\text { years of schooling }\end{array}$ & 0.48 & 0.96 & 2.91 & 4.98 & 5.93 \\
\hline $\begin{array}{l}50-64 \text { years; } \\
0 \text { years of schooling }\end{array}$ & 6.73 & 5.22 & 3.58 & 2.27 & 1.88 \\
\hline $\begin{array}{l}50-64 \text { years; } \\
1-6 \text { years of schooling }\end{array}$ & 6.89 & 6.77 & 7.21 & 7.77 & 7.66 \\
\hline $\begin{array}{l}50-64 \text { years; } \\
7-12 \text { years of schooling }\end{array}$ & 0.52 & 0.70 & 1.30 & 2.25 & 4.44 \\
\hline $\begin{array}{l}50-64 \text { years; } \\
13+\text { years of schooling }\end{array}$ & 0.20 & 0.40 & 0.76 & 1.53 & 3.25 \\
\hline Total & 100.00 & 100.00 & 100.00 & 100.00 & 100.00 \\
\hline Sample size (n) & 126,959 & 118,679 & $2,235,704$ & $2,754,866$ & $3,432,405$ \\
\hline Population size (N) & $8,506,253$ & $11,867,900$ & $22,357,040$ & $27,417,925$ & $34,203,291$ \\
\hline
\end{tabular}

Sources: 1960, 1970, 1990, 2000, and 2010 Mexican Demographic Censuses (IPUMS-International). 
Table 3. Coefficients and standard errors estimated with fixed-effects model from Equation (1) for the logarithm of mean real monthly earnings from main occupation ${ }^{+}$as the dependent variable, Brazil, 19702010.

\begin{tabular}{|c|c|c|c|c|c|}
\hline \multirow{3}{*}{$\begin{array}{l}\text { Constant } \\
\text { Age-education indicators }\end{array}$} & \multicolumn{5}{|c|}{$\begin{array}{c}\text { Coefficients } \\
\text { (Standard errors) }\end{array}$} \\
\hline & \multirow{2}{*}{$\begin{array}{c}5.340 * * * \\
(0.00374) \\
\text { Main effects } \\
\mathbf{1 9 7 0}\end{array}$} & \multicolumn{4}{|c|}{ Interactions with year } \\
\hline & & 1980 & 1991 & 2000 & 2010 \\
\hline $\begin{array}{l}15-24 \text { years; } \\
0-3 \text { years of schooling (reference group) }\end{array}$ & - & - & - & - & - \\
\hline $15-24$ years; & $0.461 * * *$ & $-0.179 * * *$ & $-0.173 * * *$ & $-0.264 * * *$ & $-0.391 * * *$ \\
\hline $4-8$ years of schooling & $(0.0116)$ & $(0.0164)$ & $(0.0164)$ & $(0.0164)$ & $(0.0166)$ \\
\hline $15-24$ years; & $1.087 * * *$ & $-0.252 * * *$ & $-0.313 * * *$ & $-0.567 * * *$ & $-0.847 * * *$ \\
\hline 9-11 years of schooling & $(0.0131)$ & $(0.0177)$ & $(0.0177)$ & $(0.0175)$ & $(0.0177)$ \\
\hline $15-24$ years & $1.566 * * *$ & $-0.274 * * *$ & $-0.357 * * *$ & $-0.491 * * *$ & $-0.893 * * *$ \\
\hline $12+$ years of schooling & $(0.0182)$ & $(0.0237)$ & $(0.0243)$ & $(0.0230)$ & $(0.0219)$ \\
\hline 25-34 years; & $0.302 * * *$ & $0.0633 * * *$ & 0.00410 & -0.00774 & $-0.0895 * * *$ \\
\hline $0-3$ years of schooling & $(0.0115)$ & $(0.0163)$ & $(0.0163)$ & $(0.0164)$ & $(0.0166)$ \\
\hline 25-34 years; & $1.061 * * *$ & $-0.115 * * *$ & $-0.259 * * *$ & $-0.328 * * *$ & $-0.643 * * *$ \\
\hline $4-8$ years of schooling & $(0.0117)$ & $(0.0165)$ & $(0.0165)$ & $(0.0165)$ & $(0.0167)$ \\
\hline $25-34$ years; & $1.760 * * *$ & $-0.198 * * *$ & $-0.345 * * *$ & $-0.511 * * *$ & $-1.073 * * *$ \\
\hline 9-11 years of schooling & $(0.0141)$ & $(0.0187)$ & $(0.0184)$ & $(0.0183)$ & $(0.0185)$ \\
\hline $25-34$ years; & $2.386 * * *$ & $-0.267 * * *$ & $-0.377 * * *$ & $-0.487 * * *$ & $-1.018 * * *$ \\
\hline $12+$ years of schooling & $(0.0161)$ & $(0.0211)$ & $(0.0212)$ & $(0.0208)$ & $(0.0201)$ \\
\hline $35-49$ years; & $0.469 * * *$ & $0.0886 * * *$ & $0.0476 * * *$ & 0.0165 & $-0.132 * * *$ \\
\hline $0-3$ years of schooling & $(0.0115)$ & $(0.0163)$ & $(0.0163)$ & $(0.0164)$ & $(0.0166)$ \\
\hline $35-49$ years; & $1.353 * * *$ & $-0.0474 * * *$ & $-0.174 * * *$ & $-0.299 * * *$ & $-0.691 * * *$ \\
\hline $4-8$ years of schooling & $(0.0118)$ & $(0.0166)$ & $(0.0166)$ & $(0.0166)$ & $(0.0168)$ \\
\hline 35-49 years; & $2.159 * * *$ & $-0.151 * * *$ & $-0.294 * * *$ & $-0.424 * * *$ & $-1.048 * * *$ \\
\hline 9-11 years of schooling & $(0.0162)$ & $(0.0210)$ & $(0.0204)$ & $(0.0200)$ & $(0.0201)$ \\
\hline $35-49$ years; & $2.671 * * *$ & $-0.215 * * *$ & $-0.215 * * *$ & $-0.253 * * *$ & $-0.852 * * *$ \\
\hline $12+$ years of schooling & $(0.0169)$ & $(0.0224)$ & $(0.0218)$ & $(0.0212)$ & $(0.0208)$ \\
\hline 50-64 years; & $0.475 * * *$ & $0.0824 * * *$ & $0.0456 * * *$ & $0.0589 * * *$ & $-0.0490 * * *$ \\
\hline $0-3$ years of schooling & $(0.0115)$ & $(0.0163)$ & $(0.0163)$ & $(0.0164)$ & $(0.0166)$ \\
\hline 50-64 years; & $1.447 * * *$ & $-0.0575 * * *$ & $-0.177 * * *$ & $-0.207 * * *$ & $-0.647 * * *$ \\
\hline $4-8$ years of schooling & $(0.0123)$ & $(0.0170)$ & $(0.0170)$ & $(0.0169)$ & $(0.0171)$ \\
\hline 50-64 years; & $2.256 * * *$ & $-0.0923 * * *$ & $-0.190 * *$ & $-0.288 * * *$ & $-0.935 * * *$ \\
\hline 9-11 years of schooling & $(0.0222)$ & $(0.0282)$ & $(0.0275)$ & $(0.0259)$ & $(0.0253)$ \\
\hline 50-64 years; & $2.675 * * *$ & $-0.128 * * *$ & $-0.104 * * *$ & $-0.0950 * * *$ & $-0.555 * * *$ \\
\hline $12+$ years of schooling & $(0.0220)$ & $(0.0287)$ & $(0.0281)$ & $(0.0265)$ & $(0.0255)$ \\
\hline Number of observations & 32,201 & & & & \\
\hline Number of groups & 2,488 & & & & \\
\hline Fraction of variance due to area-time fixed effects & 0.934 & & & & \\
\hline F $(75 ; 29,638):$ all coefficients $=0$ & $5,626.81 * * *$ & & & & \\
\hline $\mathrm{F}(2,487 ; 29,638):$ area-time fixed effects $=0$ & $29.09 * * *$ & & & & \\
\hline
\end{tabular}


Table 4. Coefficients and standard errors estimated with fixed-effects model from Equation (1) for the logarithm of mean nominal monthly earnings from main occupation as the dependent variable, Mexico, 1990-2010.

\begin{tabular}{|c|c|c|c|}
\hline Independent variables & \multicolumn{3}{|c|}{$\begin{array}{c}\text { Coefficients } \\
\text { (Standard errors) }\end{array}$} \\
\hline Constant & \multicolumn{3}{|c|}{$\begin{array}{l}9.043 * * * \\
(0.00787)\end{array}$} \\
\hline & \multirow{2}{*}{$\begin{array}{c}\text { Main effects } \\
1990 \\
\end{array}$} & \multicolumn{2}{|c|}{ Interactions with year } \\
\hline Age-education indicators & & 2000 & 2010 \\
\hline $\begin{array}{l}15-24 \text { years; } \\
0 \text { years of schooling (reference group) }\end{array}$ & - & - & - \\
\hline $15-24$ years; & $0.268 * * *$ & $-0.0900 * * *$ & $-0.102 * * *$ \\
\hline $1-6$ years of schooling & $(0.0164)$ & $(0.0230)$ & $(0.0233)$ \\
\hline 15-24 years; & $0.399 * * *$ & $-0.0856^{* * *}$ & $-0.116 * * *$ \\
\hline $7-12$ years of schooling & $(0.0166)$ & $(0.0232)$ & $(0.0234)$ \\
\hline $15-24$ years; & $0.549 * * *$ & $0.108 * * *$ & -0.00760 \\
\hline $13+$ years of schooling & $(0.0196)$ & $(0.0272)$ & $(0.0271)$ \\
\hline $25-34$ years; & $0.103 * * *$ & -0.0217 & 0.0377 \\
\hline 0 years of schooling & $(0.0182)$ & $(0.0257)$ & $(0.0260)$ \\
\hline 25-34 years; & $0.423 * * *$ & $-0.0926^{* * *}$ & $-0.0988 * * *$ \\
\hline $1-6$ years of schooling & $(0.0164)$ & $(0.0230)$ & $(0.0233)$ \\
\hline 25-34 years; & $0.704 * * *$ & $-0.0709 * * *$ & $-0.183 * * *$ \\
\hline $7-12$ years of schooling & $(0.0167)$ & $(0.0233)$ & $(0.0235)$ \\
\hline 25-34 years; & $0.987 * * *$ & $0.292 * * *$ & 0.0415 \\
\hline $13+$ years of schooling & $(0.0185)$ & $(0.0258)$ & $(0.0261)$ \\
\hline 35-49 years; & $0.187 * * *$ & $-0.0607 * *$ & -0.0321 \\
\hline 0 years of schooling & $(0.0170)$ & $(0.0239)$ & $(0.0242)$ \\
\hline 35-49 years; & $0.496 * * *$ & $-0.103 * * *$ & $-0.139 * * *$ \\
\hline $1-6$ years of schooling & $(0.0164)$ & $(0.0230)$ & $(0.0233)$ \\
\hline 35-49 years; & $0.796 * * *$ & -0.0162 & $-0.156 * * *$ \\
\hline $7-12$ years of schooling & $(0.0171)$ & $(0.0237)$ & $(0.0239)$ \\
\hline $35-49$ years; & $1.163 * * *$ & $0.372 * * *$ & $0.142 * * *$ \\
\hline $13+$ years of schooling & $(0.0189)$ & $(0.0261)$ & $(0.0264)$ \\
\hline 50-64 years; & $0.100 * * *$ & $-0.107 * * *$ & $-0.0538^{* *}$ \\
\hline 0 years of schooling & $(0.0168)$ & $(0.0235)$ & $(0.0238)$ \\
\hline 50-64 years; & $0.363 * * *$ & $-0.0460 * *$ & $-0.0762 * * *$ \\
\hline $1-6$ years of schooling & $(0.0164)$ & $(0.0230)$ & $(0.0233)$ \\
\hline 50-64 years; & $0.753 * * *$ & 0.0336 & $-0.0781 * * *$ \\
\hline $7-12$ years of schooling & $(0.0195)$ & $(0.0266)$ & $(0.0267)$ \\
\hline 50-64 years; & $1.266^{* * *}$ & $0.308 * * *$ & $0.192 * * *$ \\
\hline $13+$ years of schooling & $(0.0248)$ & $(0.0337)$ & $(0.0337)$ \\
\hline Number of observations & 82,604 & & \\
\hline Number of groups & 7,259 & & \\
\hline Fraction of variance due to area-time fixed effects & 0.968 & & \\
\hline $\mathrm{F}(45 ; 75,300):$ all coefficients $=0$ & $1,182.49 * * *$ & & \\
\hline $\mathrm{F}(7,258 ; 75,300):$ area-time fixed effects $=0$ & $22.47 * * *$ & & \\
\hline
\end{tabular}


Table 5. Coefficients and standard errors estimated with fixed-effects model from Equation (2) for the logarithm of mean real monthly earnings from main occupation ${ }^{+}$as the dependent variable, Brazil, 19702010.

\begin{tabular}{|c|c|c|c|c|c|}
\hline $\begin{array}{l}\text { Constant } \\
\text { Age-education indicators }\end{array}$ & \multicolumn{5}{|c|}{$\begin{array}{c}\text { Coefficients } \\
\text { (Standard errors) }\end{array}$} \\
\hline $\begin{array}{l}15-24 \text { years; } \\
0-3 \text { years of schooling (reference group) }\end{array}$ & - & - & - & - & - \\
\hline $\begin{array}{l}25-34 \text { years; } \\
0-3 \text { years of schooling } \\
25-34 \text { years; } \\
4-8 \text { years of schooling } \\
25-34 \text { years; } \\
9-11 \text { years of schooling } \\
25-34 \text { years; } \\
12+\text { years of schooling }\end{array}$ & $\begin{array}{l}0.344 * * * \\
(0.0427) \\
1.111 * * * \\
(0.0377) \\
1.797 * * * \\
(0.0383) \\
2.392 * * * \\
(0.0380)\end{array}$ & $\begin{array}{c}0.151 * * * \\
(0.0521) \\
-0.199 * * * \\
(0.0496) \\
-0.167 * * * \\
(0.0489) \\
-0.233 * * * \\
(0.0476)\end{array}$ & $\begin{array}{c}0.0415 \\
(0.0496) \\
-0.294 * * * \\
(0.0497) \\
-0.318 * * * \\
(0.0483) \\
-0.302 * * * \\
(0.0468)\end{array}$ & $\begin{array}{c}-0.00355 \\
(0.0480) \\
-0.447 * * * \\
(0.0525) \\
-0.573 * * * \\
(0.0474) \\
-0.519 * * * \\
(0.0451)\end{array}$ & $\begin{array}{c}-0.0821 * \\
(0.0484) \\
-0.758 * * * \\
(0.0768) \\
-1.110 * * * \\
(0.0554) \\
-1.090 * * * \\
(0.0448)\end{array}$ \\
\hline $\begin{array}{l}35-49 \text { years; } \\
0-3 \text { years of schooling } \\
35-49 \text { years; } \\
4-8 \text { years of schooling } \\
35-49 \text { years; } \\
9-11 \text { years of schooling } \\
35-49 \text { years; } \\
12+\text { years of schooling }\end{array}$ & $\begin{array}{c}0.677 * * * \\
(0.0597) \\
1.369 * * * \\
(0.0371) \\
2.137 * * * \\
(0.0395) \\
2.609 * * * \\
(0.0484)\end{array}$ & $\begin{array}{c}0.172 * * \\
(0.0707) \\
-0.0968 * * \\
(0.0489) \\
-0.146 * * * \\
(0.0497) \\
-0.199 * * * \\
(0.0484)\end{array}$ & $\begin{array}{c}0.0276 \\
(0.0673) \\
-0.139 \\
(0.0472) \\
-0.182 * * * \\
(0.0483) \\
-0.0859 \\
(0.0466)\end{array}$ & $\begin{array}{c}-0.0854 \\
(0.0650) \\
-0.336 * * \\
(0.0463) \\
-0.364 * * * \\
(0.0470) \\
-0.236 * * * \\
(0.0445)\end{array}$ & $\begin{array}{c}-0.188 * * * \\
(0.0671) \\
-0.856 * * \\
(0.0541) \\
-0.915 * * * \\
(0.0488) \\
-0.883 * * * \\
(0.0446)\end{array}$ \\
\hline & Main effects & & Interactio & with year & \\
\hline Proportions in age-education groups & 1970 & 1980 & 1991 & 2000 & 2010 \\
\hline $\begin{array}{l}\text { 15-24 years; } \\
0-3 \text { years of schooling } \\
15-24 \text { years; } \\
4-8 \text { years of schooling } \\
15-24 \text { years; } \\
9-11 \text { years of schooling } \\
15-24 \text { years; } \\
12+\text { years of schooling }\end{array}$ & $\begin{array}{c}-0.306 * * \\
(0.114) \\
-1.700 * * * \\
(0.154) \\
-11.43 * * * \\
(0.967) \\
-25.89 * * * \\
(3.201)\end{array}$ & $\begin{array}{c}0.00153^{* * *} \\
(0.158) \\
1.365^{* * *} \\
(0.220) \\
5.665^{* * *} \\
(1.070) \\
10.35 * * * \\
(3.909)\end{array}$ & $\begin{array}{c}0.204 * * * \\
(0.155) \\
1.159 * * * \\
(0.256) \\
7.521 * * * \\
(1.117) \\
12.89 * * * \\
(4.641)\end{array}$ & $\begin{array}{c}-0.429 * * \\
(0.169) \\
0.482 \\
(0.379) \\
10.08 * * * \\
(1.013) \\
23.37 * * * \\
(3.787)\end{array}$ & $\begin{array}{c}-2.622 * * * \\
(0.416) \\
0.484 \\
(0.317) \\
11.38 * * * \\
(1.074) \\
16.88 * * * \\
(3.302)\end{array}$ \\
\hline $\begin{array}{l}25-34 \text { years; } \\
0-3 \text { years of schooling } \\
25-34 \text { years; } \\
4-8 \text { years of schooling } \\
25-34 \text { years; } \\
9-11 \text { years of schooling }\end{array}$ & $\begin{array}{c}-0.677 * * * \\
(0.222) \\
-2.795 * * * \\
(0.298) \\
-14.13 * * * \\
(2.075)\end{array}$ & $\begin{array}{c}-0.640 * * * \\
(0.291) \\
2.524 * * * \\
(0.373) \\
7.791 * * * \\
(2.265)\end{array}$ & $\begin{array}{c}-0.218 \\
(0.299) \\
2.481 * * * \\
(0.371) \\
11.86 * * * \\
(2.265)\end{array}$ & $\begin{array}{c}-0.761 * * \\
(0.307) \\
2.770 * * * \\
(0.420) \\
13.05 * * * \\
(2.134)\end{array}$ & $\begin{array}{c}-1.874 * * * \\
(0.378) \\
2.476 * * * \\
(0.835) \\
12.98 * * * \\
(2.124)\end{array}$ \\
\hline
\end{tabular}




\begin{tabular}{|c|c|c|c|c|c|}
\hline $\begin{array}{l}25-34 \text { years; } \\
12+\text { years of schooling }\end{array}$ & $\begin{array}{c}-15.71 * * * \\
(2.786)\end{array}$ & $\begin{array}{c}9.321 * * * \\
(3.010)\end{array}$ & $\begin{array}{l}9.601 * * \\
(3.004)\end{array}$ & $\begin{array}{c}12.82 * * * \\
(3.025)\end{array}$ & $\begin{array}{c}14.79 * * * \\
(2.849)\end{array}$ \\
\hline 35-49 years; & $-1.392 * * *$ & $-0.677 * * *$ & 0.00364 & -0.138 & $-0.747 * *$ \\
\hline $0-3$ years of schooling & $(0.294)$ & $(0.368)$ & $(0.356)$ & $(0.354)$ & $(0.378)$ \\
\hline 35-49 years; & $-2.270 * * *$ & $1.932 * * *$ & $1.463 * *$ & $1.825 * * *$ & $2.871 * * *$ \\
\hline 4-8 years of schooling & $(0.311)$ & $(0.417)$ & $(0.381)$ & $(0.361)$ & $(0.471)$ \\
\hline 35-49 years; & $-11.47 * * *$ & $8.236 * *$ & $6.138^{*}$ & $8.418 * * *$ & $7.936 * * *$ \\
\hline 9-11 years of schooling & $(3.045)$ & $(3.518)$ & $(3.176)$ & $(3.085)$ & $(3.070)$ \\
\hline 35-49 years; & $-7.347 * *$ & $6.888^{*}$ & 2.332 & $6.277^{*}$ & $7.527 * *$ \\
\hline $12+$ years of schooling & $(3.289)$ & $(3.753)$ & $(3.443)$ & $(3.378)$ & $(3.352)$ \\
\hline 50-64 years; & $-2.380 * * *$ & $-0.891 *$ & $0.556 * *$ & 0.00884 & $0.942 *$ \\
\hline $0-3$ years of schooling & $(0.359)$ & $(0.475)$ & $(0.485)$ & $(0.468)$ & $(0.491)$ \\
\hline 50-64 years; & $-3.937 * * *$ & $-3.828 * * *$ & $2.480 * * *$ & $4.274 * * *$ & $2.678 * * *$ \\
\hline 4-8 years of schooling & $(0.663)$ & $(0.857)$ & $(0.819)$ & $(0.754)$ & $(0.829)$ \\
\hline 50-64 years; & $-27.86 * *$ & 20.93 & 12.02 & 19.51 & 19.21 \\
\hline 9-11 years of schooling & $(12.18)$ & $(13.53)$ & $(12.66)$ & $(12.32)$ & $(12.20)$ \\
\hline 50-64 years; & 1.119 & 5.357 & 0.196 & 2.032 & -5.357 \\
\hline $12+$ years of schooling & $(9.101)$ & $(10.82)$ & $(9.844)$ & $(9.331)$ & $(9.164)$ \\
\hline Number of observations & 32,201 & & & & \\
\hline Number of groups & 2,488 & & & & \\
\hline Fraction of variance due to area-time fixed effects & 0.940 & & & & \\
\hline $\mathrm{F}(155 ; 29,558):$ all coefficients $=0$ & $2,996.23 * * *$ & & & & \\
\hline $\mathrm{F}(2,487 ; 29,558):$ area-time fixed effects $=0$ & $18.07 * * *$ & & & & \\
\hline
\end{tabular}


Table 6. Coefficients and standard errors estimated with fixed-effects model from Equation (2) for the logarithm of mean nominal monthly earnings from main occupation as the dependent variable, Mexico, 1990-2010.

\begin{tabular}{|c|c|c|c|}
\hline Independent variables & \multicolumn{3}{|c|}{$\begin{array}{c}\text { Coefficients } \\
\text { (Standard errors) }\end{array}$} \\
\hline Constant & \multicolumn{3}{|c|}{$\begin{array}{l}9.021 * * * \\
(0.0144)\end{array}$} \\
\hline & Main effects & \multicolumn{2}{|c|}{ Interactions with year } \\
\hline Age-education indicators & 1990 & 2000 & 2010 \\
\hline $\begin{array}{l}15-24 \text { years; } \\
0 \text { years of schooling (reference group) }\end{array}$ & - & - & - \\
\hline $15-24$ years; & $0.192 * * *$ & -0.0496 & -0.0321 \\
\hline $1-6$ years of schooling & $(0.0356)$ & $(0.0494)$ & $(0.0498)$ \\
\hline 15-24 years; & $0.573 * * *$ & $-0.252 * * *$ & $-0.306 * * *$ \\
\hline $7-12$ years of schooling & $(0.0656)$ & $(0.0886)$ & $(0.0877)$ \\
\hline $15-24$ years; & $0.505 * * *$ & $0.266 * * *$ & 0.0859 \\
\hline $13+$ years of schooling & $(0.0408)$ & $(0.0566)$ & $(0.0557)$ \\
\hline 25-34 years; & $0.175^{* * *}$ & -0.00551 & 0.0381 \\
\hline 0 years of schooling & $(0.0333)$ & $(0.0469)$ & $(0.0472)$ \\
\hline $25-34$ years; & $0.378 * * *$ & -0.0536 & -0.0335 \\
\hline $1-6$ years of schooling & $(0.0420)$ & $(0.0582)$ & $(0.0585)$ \\
\hline 25-34 years; & $0.876 * * *$ & $-0.180 * * *$ & $-0.306 * * *$ \\
\hline $7-12$ years of schooling & $(0.0409)$ & $(0.0561)$ & $(0.0561)$ \\
\hline $25-34$ years; & $0.952 * * *$ & $0.368 * * *$ & $0.0863 *$ \\
\hline $13+$ years of schooling & $(0.0352)$ & $(0.0489)$ & $(0.0492)$ \\
\hline $35-49$ years; & $0.196 * * *$ & 0.0225 & 0.0453 \\
\hline 0 years of schooling & $(0.0320)$ & $(0.0448)$ & $(0.0452)$ \\
\hline 35-49 years; & $0.534 * * *$ & -0.0364 & $-0.131 *$ \\
\hline $1-6$ years of schooling & $(0.0496)$ & $(0.0685)$ & $(0.0686)$ \\
\hline 35-49 years; & $0.874 * * *$ & -0.0624 & $-0.201 * * *$ \\
\hline $7-12$ years of schooling & $(0.0388)$ & $(0.0522)$ & $(0.0523)$ \\
\hline $35-49$ years; & $1.045 * * *$ & $0.485 * * *$ & $0.241 * * *$ \\
\hline $13+$ years of schooling & $(0.0350)$ & $(0.0482)$ & $(0.0486)$ \\
\hline 50-64 years; & $0.0931 * * *$ & -0.0369 & 0.0477 \\
\hline 0 years of schooling & $(0.0323)$ & $(0.0452)$ & $(0.0456)$ \\
\hline 50-64 years; & $0.433 * * *$ & -0.00721 & -0.0662 \\
\hline $1-6$ years of schooling & $(0.0391)$ & $(0.0538)$ & $(0.0540)$ \\
\hline 50-64 years; & $0.682 * * *$ & $0.106^{*}$ & 0.0580 \\
\hline $7-12$ years of schooling & $(0.0423)$ & $(0.0571)$ & $(0.0570)$ \\
\hline 50-64 years; & $1.067 * * *$ & $0.463 * * *$ & $0.331 * * *$ \\
\hline \multirow[t]{2}{*}{$13+$ years of schooling } & $(0.0457)$ & $(0.0619)$ & $(0.0620)$ \\
\hline & Main effects & \multicolumn{2}{|c|}{ Interaction with year } \\
\hline Proportions in age-education groups & 1990 & 2000 & 2010 \\
\hline 15-24 years; & 1.013 & 0.479 & -0.0260 \\
\hline 0 years of schooling & $(1.077)$ & $(1.486)$ & $(1.494)$ \\
\hline 15-24 years; & $0.819 * * *$ & -0.254 & $-0.594^{*}$ \\
\hline $1-6$ years of schooling & $(0.222)$ & $(0.307)$ & $(0.306)$ \\
\hline $15-24$ years; & $-0.794 * * *$ & $0.894 * *$ & $0.973 * *$ \\
\hline $7-12$ years of schooling & $(0.294)$ & $(0.394)$ & $(0.388)$ \\
\hline $15-24$ years; & $2.359 *$ & $-5.845 * * *$ & $-3.491 * *$ \\
\hline $13+$ years of schooling & $(1.210)$ & $(1.671)$ & $(1.623)$ \\
\hline 25-34 years; & $-2.422 * *$ & -0.260 & 0.0507 \\
\hline 0 years of schooling & $(0.946)$ & $(1.338)$ & $(1.315)$ \\
\hline 25-34 years; & $0.587 *$ & -0.258 & -0.593 \\
\hline $1-6$ years of schooling & $(0.325)$ & $(0.447)$ & $(0.446)$ \\
\hline 25-34 years; & $-1.687 * * *$ & $1.309 * * *$ & $1.361 * * *$ \\
\hline $7-12$ years of schooling & $(0.318)$ & $(0.433)$ & $(0.429)$ \\
\hline
\end{tabular}




\begin{tabular}{|c|c|c|c|}
\hline $\begin{array}{l}25-34 \text { years; } \\
13+\text { years of schooling }\end{array}$ & $\begin{array}{l}1.630 * * \\
(0.722)\end{array}$ & $\begin{array}{c}-2.047 * * \\
(1.004)\end{array}$ & $\begin{array}{l}-1.196 \\
(1.002)\end{array}$ \\
\hline $35-49$ years; & 0.252 & $-2.031 * * *$ & $-2.114 * * *$ \\
\hline 0 years of schooling & $(0.537)$ & $(0.755)$ & $(0.745)$ \\
\hline 35-49 years; & -0.151 & -0.371 & -0.0302 \\
\hline $1-6$ years of schooling & $(0.293)$ & $(0.401)$ & $(0.399)$ \\
\hline 35-49 years; & $-0.841 * *$ & $0.795^{*}$ & 0.663 \\
\hline $7-12$ years of schooling & $(0.355)$ & $(0.469)$ & $(0.465)$ \\
\hline 35-49 years; & $4.415 * * *$ & $-3.178 * * *$ & $-2.985 * * *$ \\
\hline $13+$ years of schooling & $(0.690)$ & $(0.950)$ & $(0.949)$ \\
\hline 50-64 years; & 0.559 & $-1.336^{* *}$ & $-2.269 * * *$ \\
\hline 0 years of schooling & $(0.452)$ & $(0.631)$ & $(0.624)$ \\
\hline 50-64 years; & $-0.516^{*}$ & -0.233 & -0.0457 \\
\hline $1-6$ years of schooling & $(0.272)$ & $(0.367)$ & $(0.364)$ \\
\hline 50-64 years; & $3.629 * * *$ & -2.400 & $-5.520 * * *$ \\
\hline $7-12$ years of schooling & $(1.360)$ & $(1.810)$ & $(1.790)$ \\
\hline $50-64$ years; & $13.25 * * *$ & $-8.540 * * *$ & $-7.980 * * *$ \\
\hline $13+$ years of schooling & $(2.008)$ & $(2.686)$ & $(2.678)$ \\
\hline Number of observations & 82,604 & & \\
\hline Number of groups & 7,259 & & \\
\hline Fraction of variance due to area-time fixed effects & 0.968 & & \\
\hline $\mathrm{F}(93 ; 75,252):$ all coefficients $=0$ & $577.32 * * *$ & & \\
\hline$F(7,258 ; 75,252)$ : area-time fixed effects $=0$ & $12.21 * * *$ & & \\
\hline
\end{tabular}

* Significant at $\mathrm{p}<0.1,{ }^{* *}$ Significant at $\mathrm{p}<0.05, * * *$ Significant at $\mathrm{p}<0.01$.

Standard errors are reported in parentheses.

Sources: 1990, 2000, and 2010 Mexican Demographic Censuses (IPUMS-International). 
Table 7. Effects of proportion of male working-age population by age-education groups (factor-price elasticities) on mean real monthly earnings from main occupation ${ }^{+}$(dependent variable), based on Equation (2) (Table 5), using the national age-education distribution (Table 1), Brazil, 1970-2010.

\begin{tabular}{|c|c|c|c|c|c|}
\hline \multirow{2}{*}{ Age-education groups } & \multicolumn{5}{|c|}{ Elasticities } \\
\hline & 1970 & 1980 & 1991 & 2000 & 2010 \\
\hline $\begin{array}{l}15-24 \text { years; } \\
0-3 \text { years of schooling }\end{array}$ & -0.061 & -0.040 & -0.010 & -0.070 & -0.066 \\
\hline $\begin{array}{l}\text { 15-24 years; } \\
4-8 \text { years of schooling }\end{array}$ & -0.230 & -0.059 & -0.091 & -0.189 & -0.111 \\
\hline $\begin{array}{l}\text { 15-24 years; } \\
9-11 \text { years of schooling }\end{array}$ & -0.248 & -0.284 & -0.198 & -0.121 & -0.006 \\
\hline $\begin{array}{l}15-24 \text { years; } \\
12+\text { years of schooling }\end{array}$ & -0.147 & -0.161 & -0.118 & -0.031 & -0.274 \\
\hline $\begin{array}{l}25-34 \text { years; } \\
0-3 \text { years of schooling }\end{array}$ & -0.099 & -0.133 & -0.069 & -0.080 & -0.098 \\
\hline $\begin{array}{l}25-34 \text { years; } \\
4-8 \text { years of schooling }\end{array}$ & -0.197 & -0.028 & -0.036 & -0.003 & -0.024 \\
\hline $\begin{array}{l}25-34 \text { years; } \\
9-11 \text { years of schooling }\end{array}$ & -0.165 & -0.172 & -0.115 & -0.064 & -0.106 \\
\hline $\begin{array}{l}25-34 \text { years; } \\
12+\text { years of schooling }\end{array}$ & -0.130 & -0.132 & -0.143 & -0.063 & -0.042 \\
\hline $\begin{array}{l}35-49 \text { years; } \\
0-3 \text { years of schooling }\end{array}$ & -0.243 & -0.269 & -0.144 & -0.121 & -0.172 \\
\hline $\begin{array}{l}35-49 \text { years; } \\
4-8 \text { years of schooling }\end{array}$ & -0.154 & -0.029 & -0.084 & -0.054 & 0.057 \\
\hline $\begin{array}{l}35-49 \text { years; } \\
9-11 \text { years of schooling }\end{array}$ & -0.096 & -0.047 & -0.161 & -0.163 & -0.272 \\
\hline $\begin{array}{l}35-49 \text { years; } \\
12+\text { years of schooling }\end{array}$ & -0.055 & -0.006 & -0.126 & -0.033 & 0.007 \\
\hline $\begin{array}{l}50-64 \text { years; } \\
0-3 \text { years of schooling }\end{array}$ & -0.248 & -0.284 & -0.143 & -0.160 & -0.121 \\
\hline $\begin{array}{l}50-64 \text { years; } \\
4-8 \text { years of schooling }\end{array}$ & -0.121 & -0.323 & -0.070 & 0.019 & -0.050 \\
\hline $\begin{array}{l}50-64 \text { years; } \\
9-11 \text { years of schooling }\end{array}$ & -0.078 & -0.037 & -0.144 & -0.126 & -0.321 \\
\hline $\begin{array}{l}50-64 \text { years; } \\
12+\text { years of schooling }\end{array}$ & 0.004 & 0.034 & 0.011 & 0.042 & -0.099 \\
\hline Standard deviation & 0.077 & 0.115 & $\mathbf{0 . 0 5 7}$ & 0.067 & 0.107 \\
\hline
\end{tabular}

${ }^{+}$Nominal earnings were converted to base 1 in January 2002, taking into account changes in currency and inflation (Corseuil and Foguel 2002). Sources: 1970, 1980, 1991, 2000, and 2010 Brazilian Demographic Censuses (Brazilian Institute of Geography and Statistics - IBGE). 
Table 8. Effects of proportion of male working-age population by age-education groups (factor-price elasticities) on mean nominal monthly earnings from main occupation (dependent variable), based on Equation (2) (Table 6), using the national age-education distribution (Table 2), Mexico, 1990-2010.

\begin{tabular}{|c|c|c|c|}
\hline \multirow[t]{2}{*}{ Age-education groups } & \multicolumn{3}{|c|}{ Elasticities } \\
\hline & 1990 & 2000 & 2010 \\
\hline $\begin{array}{l}15-24 \text { years; } \\
0 \text { years of schooling }\end{array}$ & 0.019 & 0.014 & 0.004 \\
\hline $\begin{array}{l}15-24 \text { years; } \\
1-6 \text { years of schooling }\end{array}$ & 0.100 & 0.050 & 0.010 \\
\hline $\begin{array}{l}\text { 15-24 years; } \\
7-12 \text { years of schooling }\end{array}$ & -0.168 & 0.021 & 0.038 \\
\hline $\begin{array}{l}15-24 \text { years; } \\
13+\text { years of schooling }\end{array}$ & 0.063 & -0.099 & -0.043 \\
\hline $\begin{array}{l}25-34 \text { years; } \\
0 \text { years of schooling }\end{array}$ & -0.048 & -0.024 & -0.016 \\
\hline $\begin{array}{l}25-34 \text { years; } \\
1-6 \text { years of schooling }\end{array}$ & 0.060 & 0.026 & 0.000 \\
\hline $\begin{array}{l}25-34 \text { years; } \\
7-12 \text { years of schooling }\end{array}$ & -0.145 & -0.049 & -0.040 \\
\hline $\begin{array}{l}25-34 \text { years; } \\
13+\text { years of schooling }\end{array}$ & 0.069 & -0.018 & 0.023 \\
\hline $\begin{array}{l}35-49 \text { years; } \\
0 \text { years of schooling }\end{array}$ & 0.009 & -0.030 & -0.023 \\
\hline $\begin{array}{l}35-49 \text { years; } \\
1-6 \text { years of schooling }\end{array}$ & -0.019 & -0.059 & -0.015 \\
\hline $\begin{array}{l}35-49 \text { years; } \\
7-12 \text { years of schooling }\end{array}$ & -0.040 & -0.004 & -0.024 \\
\hline $\begin{array}{l}35-49 \text { years; } \\
13+\text { years of schooling }\end{array}$ & 0.129 & 0.062 & 0.085 \\
\hline $\begin{array}{l}50-64 \text { years; } \\
0 \text { years of schooling }\end{array}$ & 0.020 & -0.018 & -0.032 \\
\hline $\begin{array}{l}50-64 \text { years; } \\
1-6 \text { years of schooling }\end{array}$ & -0.037 & -0.058 & -0.043 \\
\hline $\begin{array}{l}50-64 \text { years; } \\
7-12 \text { years of schooling }\end{array}$ & 0.047 & 0.028 & -0.084 \\
\hline $\begin{array}{l}50-64 \text { years; } \\
13+\text { years of schooling }\end{array}$ & 0.101 & 0.072 & 0.171 \\
\hline Standard deviation & 0.084 & 0.048 & 0.060 \\
\hline
\end{tabular}

Sources: 1990, 2000, and 2010 Mexican Demographic Censuses (IPUMS-International). 
Table 9. Coefficients and standard errors estimated with model from Equation (4) for the logarithm of individual earnings as the dependent variable by income quartile, Brazil, 2000 and 2010.

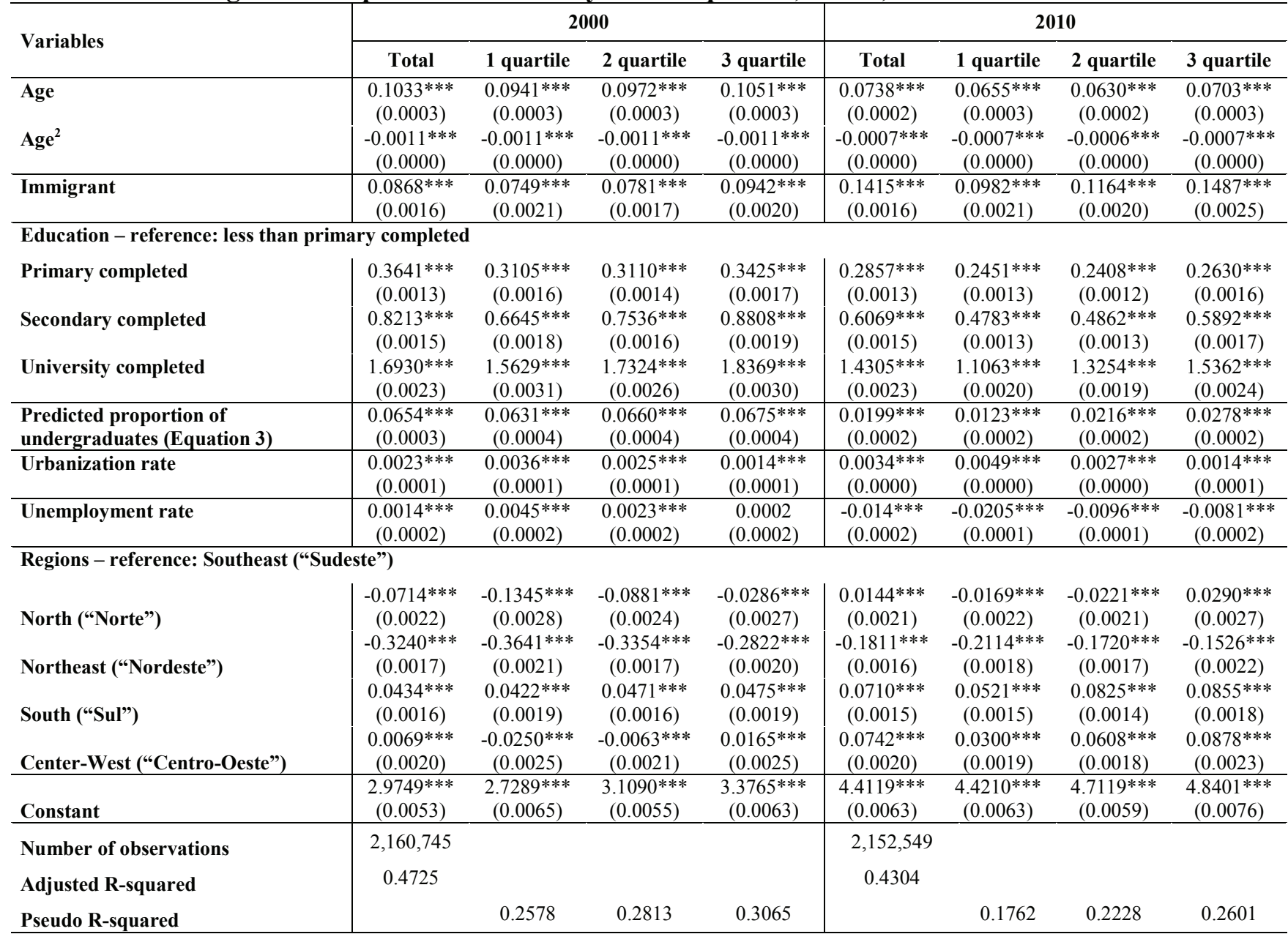

* Significant at $\mathrm{p}<0.1, * *$ Significant at $\mathrm{p}<0.05, * * *$ Significant at $\mathrm{p}<0.01$

Standard errors are reported in parentheses.

Sources: 1991, 2000, and 2010 Brazilian Demographic Censuses (IPUMS-International). 
Table 10. Coefficients and standard errors estimated with model from Equation (4) for the logarithm of individual earnings as the dependent variable by income quartile, Mexico, 2000 and 2010.

\begin{tabular}{|c|c|c|c|c|c|c|c|c|}
\hline \multirow{2}{*}{ Variables } & \multicolumn{4}{|c|}{2000} & \multicolumn{4}{|c|}{2010} \\
\hline & Total & 1 quartile & 2 quartile & 3 quartile & Total & 1 quartile & 2 quartile & 3 quartile \\
\hline Age & $\begin{array}{c}0.0644 * * * \\
(0.0003)\end{array}$ & $\begin{array}{c}0.0530 * * * \\
(0.0003)\end{array}$ & $\begin{array}{c}0.0530 * * * \\
(0.0002)\end{array}$ & $\begin{array}{c}0.0585 * * * \\
(0.0003)\end{array}$ & $\begin{array}{c}0.0613 * * * \\
(0.0003)\end{array}$ & $\begin{array}{c}0.0575 * * * \\
(0.0003)\end{array}$ & $\begin{array}{c}0.0495 * * * \\
(0.0002)\end{array}$ & $\begin{array}{c}0.0497 * * * \\
(0.0003)\end{array}$ \\
\hline Age2 & $\begin{array}{c}-0.0007 * * * \\
(0.0000)\end{array}$ & $\begin{array}{c}-0.0006 * * * \\
(0.0000)\end{array}$ & $\begin{array}{c}-0.0006 * * * \\
(0.0000)\end{array}$ & $\begin{array}{c}-0.0007 * * * \\
(0.0000)\end{array}$ & $\begin{array}{c}-0.0007 * * * \\
(0.0000)\end{array}$ & $\begin{array}{c}-0.0007 * * * \\
(0.0000)\end{array}$ & $\begin{array}{c}-0.0006 * * * \\
(0.0000)\end{array}$ & $\begin{array}{c}-0.0005 * * * \\
(0.0000)\end{array}$ \\
\hline Immigrant & $\begin{array}{c}0.1322 * * * \\
(0.0017)\end{array}$ & $\begin{array}{c}0.1138 * * * \\
(0.0019)\end{array}$ & $\begin{array}{c}0.1133 * * * \\
(0.0016)\end{array}$ & $\begin{array}{c}0.1323 * * * \\
(0.0018)\end{array}$ & $\begin{array}{c}0.1333 * * * \\
(0.0017)\end{array}$ & $\begin{array}{c}0.1213 * * * \\
(0.0022)\end{array}$ & $\begin{array}{c}0.1183 * * * \\
(0.0017)\end{array}$ & $\begin{array}{c}0.1285^{* * *} * \\
(0.0018)\end{array}$ \\
\hline \multicolumn{9}{|c|}{ Education - reference: less than primary completed } \\
\hline Primary completed & $\begin{array}{c}0.2696 * * * \\
(0.0014)\end{array}$ & $\begin{array}{c}0.2149 * * * \\
(0.0014)\end{array}$ & $\begin{array}{c}0.2220 * * * \\
(0.0012)\end{array}$ & $\begin{array}{c}0.2563 * * * \\
(0.0015)\end{array}$ & $\begin{array}{c}0.2606 * * * \\
(0.0016)\end{array}$ & $\begin{array}{c}0.2778 * * * \\
(0.0017)\end{array}$ & $\begin{array}{c}0.2338 * * * \\
(0.0013)\end{array}$ & $\begin{array}{c}0.2292 * * * \\
(0.0015)\end{array}$ \\
\hline Secondary completed & $\begin{array}{c}0.6527 * * * \\
(0.0018)\end{array}$ & $\begin{array}{c}0.5084 * * * \\
(0.0020)\end{array}$ & $\begin{array}{c}0.6027 * * * \\
(0.0017)\end{array}$ & $\begin{array}{c}0.7550 * * * \\
(0.0020)\end{array}$ & $\begin{array}{c}0.5453 * * * \\
(0.0019)\end{array}$ & $\begin{array}{c}0.4966 * * * \\
(0.0022)\end{array}$ & $\begin{array}{c}0.4751 * * * \\
(0.0017)\end{array}$ & $\begin{array}{c}0.5323 * * * \\
(0.0019)\end{array}$ \\
\hline University completed & $\begin{array}{c}1.2598 * * * \\
(0.0020)\end{array}$ & $\begin{array}{c}1.1315 * * * \\
(0.0022)\end{array}$ & $\begin{array}{c}1.2820 * * * \\
(0.0019)\end{array}$ & $\begin{array}{c}1.4318 * * * \\
(0.0022)\end{array}$ & $\begin{array}{c}1.0709 * * * \\
(0.0021)\end{array}$ & $\begin{array}{c}0.9728 * * * \\
(0.0027)\end{array}$ & $\begin{array}{c}1.0231 * * * \\
(0.0021)\end{array}$ & $\begin{array}{c}1.1503 * * * \\
(0.0023)\end{array}$ \\
\hline $\begin{array}{l}\text { Predicted proportion of } \\
\text { undergraduates (from Equation 3) }\end{array}$ & $\begin{array}{c}0.0511 * * * \\
(0.0004)\end{array}$ & $\begin{array}{c}0.0433 * * * \\
(0.0004)\end{array}$ & $\begin{array}{c}0.0400 * * * \\
(0.0003)\end{array}$ & $\begin{array}{c}0.0375 * * * \\
(0.0004)\end{array}$ & $\begin{array}{c}0.0307 * * * \\
(0.0001)\end{array}$ & $\begin{array}{c}0.0349 * * * \\
(0.0002)\end{array}$ & $\begin{array}{c}0.0299 * * * \\
(0.0001)\end{array}$ & $\begin{array}{c}0.0292 * * * \\
(0.0001)\end{array}$ \\
\hline Urbanization rate & $\begin{array}{c}0.0021 * * * \\
(0.0000)\end{array}$ & $\begin{array}{c}0.0024 * * * \\
(0.0000)\end{array}$ & $\begin{array}{c}0.0019 * * * \\
(0.0000)\end{array}$ & $\begin{array}{c}0.0018 * * * \\
(0.0000)\end{array}$ & & & & \\
\hline Unemployment rate & $\begin{array}{c}-0.0124 * * * \\
(0.0009)\end{array}$ & $\begin{array}{c}0.0007 \\
(0.0008)\end{array}$ & $\begin{array}{c}0.0021 * * * \\
(0.0007)\end{array}$ & $\begin{array}{c}0.0016 \\
(0.0008)\end{array}$ & $\begin{array}{c}-0.0013 * * * \\
(0.0003)\end{array}$ & $\begin{array}{c}0.0049 * * * \\
(0.0003)\end{array}$ & $\begin{array}{c}0.0038 * * * \\
(0.0002)\end{array}$ & $\begin{array}{c}0.0036 * * * \\
(0.0002)\end{array}$ \\
\hline \multicolumn{9}{|c|}{ Regions - reference: Northeast ("Nordeste") } \\
\hline Northwest ("Noroeste") & $\begin{array}{c}0.0143 * * * \\
(0.0021)\end{array}$ & $\begin{array}{c}-0.0084 * * * \\
(0.0025)\end{array}$ & $\begin{array}{c}0.0082 * * * \\
(0.0021)\end{array}$ & $\begin{array}{c}0.0261 * * * \\
(0.0024)\end{array}$ & $\begin{array}{c}0.0646^{* * * *} \\
(0.0021)\end{array}$ & $\begin{array}{c}-0.0137 * * * \\
(0.0031)\end{array}$ & $\begin{array}{c}0.0023 \\
(0.0024)\end{array}$ & $\begin{array}{c}0.0169 * * * \\
(0.0026)\end{array}$ \\
\hline West ("Ocidente") & $\begin{array}{c}-0.0198 * * * \\
(0.0020)\end{array}$ & $\begin{array}{c}-0.0071 * * * \\
(0.0022)\end{array}$ & $\begin{array}{l}0.0036^{*} \\
(0.0019)\end{array}$ & $\begin{array}{c}-0.0089 * * * \\
(0.0022)\end{array}$ & $\begin{array}{c}0.1565 * * * \\
(0.0021)\end{array}$ & $\begin{array}{c}0.1085 * * * \\
(0.0027)\end{array}$ & $\begin{array}{c}0.1191 * * * \\
(0.0021)\end{array}$ & $\begin{array}{c}0.1083 * * * \\
(0.0023)\end{array}$ \\
\hline East ("Oriente") & $\begin{array}{c}-0.3259 * * * \\
(0.0019)\end{array}$ & $\begin{array}{c}-0.3670 * * * \\
(0.0021)\end{array}$ & $\begin{array}{c}-0.3414 * * * \\
(0.0017)\end{array}$ & $\begin{array}{c}-0.3223 * * * \\
(0.0021)\end{array}$ & $\begin{array}{c}-0.0963 * * * \\
(0.0020)\end{array}$ & $\begin{array}{c}-0.2148 * * * \\
(0.0025)\end{array}$ & $\begin{array}{c}-0.1666 * * * \\
(0.0019)\end{array}$ & $\begin{array}{c}-0.1334 * * * \\
(0.0021)\end{array}$ \\
\hline Center-North ("Centro-Norte") & $\begin{array}{c}-0.0129 * * * \\
(0.0021)\end{array}$ & $\begin{array}{c}-0.0523 * * * \\
(0.0024)\end{array}$ & $\begin{array}{c}-0.0363 * * * \\
(0.0020)\end{array}$ & $\begin{array}{c}-0.0428 * * * \\
(0.0024)\end{array}$ & $\begin{array}{c}0.0686 * * * \\
(0.0021)\end{array}$ & $\begin{array}{l}-0.0041 \\
(0.0029)\end{array}$ & $\begin{array}{c}0.0122 * * * \\
(0.0023)\end{array}$ & $\begin{array}{c}0.0087 * * * \\
(0.0025)\end{array}$ \\
\hline Center-South (“Centro-Sul”) & $\begin{array}{c}-0.1978 * * * \\
(0.0017)\end{array}$ & $\begin{array}{c}-0.2051 * * * \\
(0.0020)\end{array}$ & $\begin{array}{c}-0.1997 * * * \\
(0.0016)\end{array}$ & $\begin{array}{c}-0.1943 * * * \\
(0.0019)\end{array}$ & $\begin{array}{c}-0.0209 * * \\
(0.0017)\end{array}$ & $\begin{array}{c}-0.0892 * * * \\
(0.0026)\end{array}$ & $\begin{array}{c}-0.0493 * * * \\
(0.0020)\end{array}$ & $\begin{array}{c}-0.0310 * * * \\
(0.0022)\end{array}$ \\
\hline Southeast ("Sudeste") & $\begin{array}{c}-0.3230 * * * \\
(0.0025)\end{array}$ & $\begin{array}{c}-0.4305 * * * \\
(0.0027)\end{array}$ & $\begin{array}{c}-0.3553 * * * \\
(0.0023)\end{array}$ & $\begin{array}{c}-0.3092 * * * \\
(0.0027)\end{array}$ & $\begin{array}{c}-0.0453 * * * \\
(0.0026)\end{array}$ & $\begin{array}{c}-0.2154 * * * \\
(0.0032)\end{array}$ & $\begin{array}{c}-0.1675 * * * \\
(0.0025)\end{array}$ & $\begin{array}{c}-0.1235^{* * *} \\
(0.0027)\end{array}$ \\
\hline Southwest ("Sudoeste") & $\begin{array}{c}-0.3937 * * * \\
(0.0024)\end{array}$ & $\begin{array}{c}-0.4285 * * * \\
(0.0025)\end{array}$ & $\begin{array}{c}-0.3511 * * * \\
(0.0021)\end{array}$ & $\begin{array}{c}-0.3036 * * * \\
(0.0025)\end{array}$ & $\begin{array}{c}-0.1909 * * * \\
(0.0025)\end{array}$ & $\begin{array}{c}-0.3178 * * * \\
(0.0027)\end{array}$ & $\begin{array}{c}-0.1909 * * * \\
(0.0021)\end{array}$ & $\begin{array}{c}-0.1099 * * * \\
(0.0023)\end{array}$ \\
\hline Constant & $\begin{array}{c}5.7328 * * * \\
(0.0050)\end{array}$ & $\begin{array}{c}5.7694 * * * \\
(0.0053)\end{array}$ & $\begin{array}{c}6.0856 * * * \\
(0.0044)\end{array}$ & $\begin{array}{c}6.2589 * * * \\
(0.0053)\end{array}$ & $\begin{array}{c}6.4723 * * * \\
(0.0055)\end{array}$ & $\begin{array}{c}6.2892 * * * \\
(0.0064)\end{array}$ & $\begin{array}{c}6.8100 * * * \\
(0.0049)\end{array}$ & $\begin{array}{c}7.0816 * * * \\
(0.0053)\end{array}$ \\
\hline Number of observations & $1,733,425$ & & & & $1,900,108$ & & & \\
\hline Adjusted R-squared & 0.3928 & & & & 0.2807 & & & \\
\hline Pseudo R-squared & & 0.2174 & 0.2452 & 0.2763 & & 0.1511 & 0.1590 & 0.1890 \\
\hline
\end{tabular}

* Significant at $\mathrm{p}<0.1, * *$ Significant at $\mathrm{p}<0.05, * * *$ Significant at $\mathrm{p}<0.01$

Standard errors are reported in parentheses.

Sources: 1990, 2000, and 2010 Mexican Demographic Censuses (IPUMS-International). 
Figure 1. Coefficients of predicted proportion of undergraduates (from Tables 9 and 10) for the logarithm of individual earnings as the dependent variable by income quartile, Brazil and Mexico, 2000 and 2010.

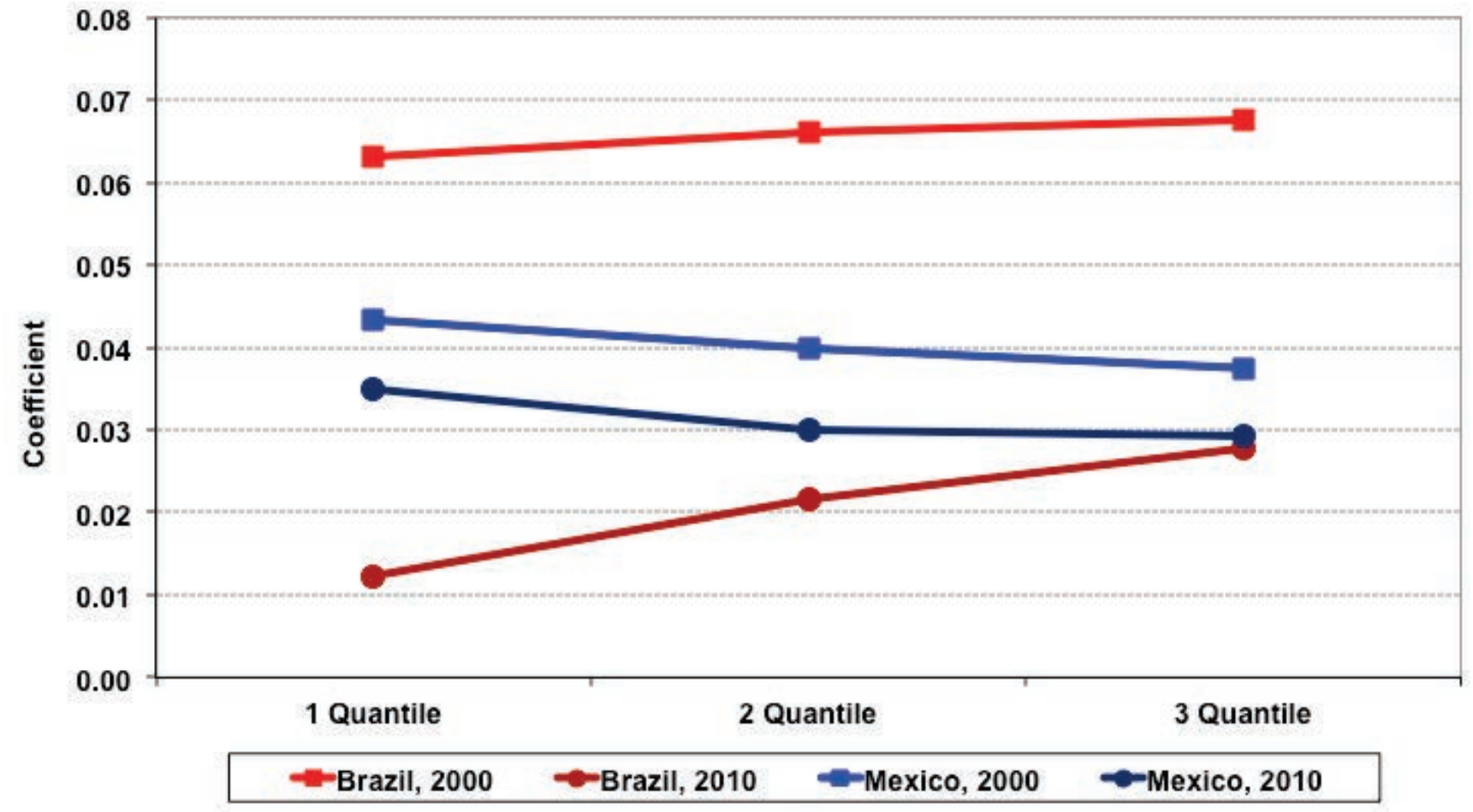

Source: Brazilian and Mexican Demographic Censuses (IPUMS-International). 


\section{References}

1. Barro RJ, Lee JW. International data on educational attainment: Updates and implications. Oxford Economic Papers. 2001; 53:541-63.

2. Lam D, Marteleto L. Small families and large cohorts: The impact of the demographic transition on schooling in Brazil. In: Lloyd CB, Behrman JR, Stromquist NP, Cohen B, editors. The Changing Transitions to Adulthood in Developing Countries: Selected Studies. Washington, DC: The National Academies Press; 2005. p. 56-83.

3. Lam D, Marteleto L. Stages of the demographic transition from a child's perspective: Family size, cohort size, and children's resources. Population and Development Review. 2008; 34:225-52.

4. Marcílio ML. Why are Brazil's public schools so weak? Backwardness in education. Braudel Papers. 2001; 30:3-11.

5. Marcílio ML. História da Escola em São Paulo e no Brasil. São Paulo: Imprensa Oficial do Estado; 2005 .

6. Potter JE, Schmertmann CP, Assunção RM, Cavenaghi SM. Mapping the timing, pace, and scale of the fertility transition in Brazil. Population and Development Review. 2010; 36:283-307.

7. Potter JE, Schmertmann CP, Cavenaghi SM. Fertility and development: evidence from Brazil. Demography. 2002; 39:739-61.

8. Riani JLR. Determinantes do resultado educacional no Brasil: Família, perfil escolar dos municípios e dividendo demográfico numa abordagem hierárquica e espacial. Belo Horizonte: Universidade Federal de Minas Gerais (UFMG); 2005.

9. Gong X, Van Soest A. Wage differentials and mobility in the urban labour market: A panel data analysis for Mexico. Labour Economics. 2002; 9:513-29.

10. Lustig N, Lopez-Calva L, Ortiz-Juarez E. Declining inequality in Latin America in the 2000s: The cases of Argentina, Brazil, and Mexico. World Dev. 2013; 44:129-41.

11. Rios-Neto ELG, Guimarães RRM. The demography of education in Brazil: Inequality of educational opportunities based on grade progression probability (1986-2008). Vienna Yearbook of Population Research. 2010; 8:283-312.

12. Berry C, Glaeser E. The divergence of human capital levels across cities. Papers in Regional Science. 2005; 84:407-44.

13. Moretti E. Workers' education, spillovers, and productivity: Evidence from plant-level production functions. The American Economic Review 2004; 94:656-90.

14. Moretti E. Estimating the social return to higher education: Evidence from longitudinal and repeated cross-sectional data. Journal of Econometrics. 2004; 121:175-212.

15. Moretti E. Human capital externalities in cities. In: Henderson JV, Thisse J-F, editors. Handbook of Urban and Regional Economics. Amsterdam: North-Holland; 2004. p. 2063-3073.

16. Moretti E. Local labor markets. In: Ashenfelter O, Card D, editors. Handbook of Labor Economics. Amsterdam: North-Holland; 2011. p. 1237-313.

17. Hout M. Social and economic returns to college education in the United States. Annual Review of Sociology. 2012; 38:379-400.

18. Black D. Local human capital externalities: educational segregation and inequality. Manuscript, London School of Economics. 1998.

19. Rauch JE. Productivity gains from geographic concentration of human capital: Evidence from cities. Journal of Urban Economics. 1993; 34:380-400.

20. Queiroz BL, Golgher AB. Human capital differentials across municipalities and states in Brazil. Population Review. 2008; 47:25-49.

21. Queiroz BL, Calazans JA. Os efeitos da concentração de capital humano no retorno privado e social da educaçao no Brasil. In: ABEP, editor. XVII Encontro Nacional de Estudos Populacionais; Caxambu, Brazil: Associação Brasileira de Estudos Populacionais (ABEP); 2010.

22. Amaral EFL, Potter JE, Hamermesh DS, Rios-Neto ELG. Age, education and earnings in the course of Brazilian development: does composition matter? Demographic Research. 2013; 28:581-612.

23. Amaral EFL. The decomposition of economic outcomes as a result of changes in Brazil's male ageeducation structure. Population Research and Policy Review. 2012; 31:883-905. 
24. Amaral EFL, Almeida ME, Rios-Neto ELG, Potter JE. Effects of the age-education structure of female workers on male earnings in Brazil. Poverty \& Public Policy. 2013; 5:336-53.

25. Amaral EFL, Rios-Neto ELG, Potter JE. Long term influences of age-education transition on the Brazilian labour market. Bulletin of Latin American Research. 2012; 31:302-19.

26. Amaral EFL, Rios-Neto ELG, Potter JE. Influences of transition in age-education structure and internal migration on the labour market in Brazil. Informe GEPEC. 2011; 15:44-71.

27. Rigotti JIR. Geography of population flow according to the migrants educational level. Estudos Avançados. 2006; 20:237-54.

28. Berger M. The effect of cohort size on earnings growth: a reexamination of the evidence. The Journal of Political Economy. 1985; 93:561-73.

29. Biagi F, Lucifora C. Demographic and education effects on unemployment in Europe. Labour Economics. 2008; 15:1076-101.

30. Brunello G. The effects of cohort size on European earnings. Journal of Population Economics. 2010; 23:273-90.

31. Easterlin RA. What will 1984 be like? Socioeconomic implications of recent twists in age structure. Demography. 1978; 15:397-432.

32. Freeman RB. The effect of demographic factors on age-earnings profiles. The Journal of Human Resources. 1979; 14:289-318.

33. Katz LF, Autor DH. Changes in the wage structure and earnings inequality. In: Ashenfelter O, Card D, editors. Handbook of Labor Economics. Amsterdam: North-Holland; 1999. p. 1463-555.

34. Katz LF, Murphy KM. Changes in relative wages, 1963-1987: supply and demand factors. The Quarterly Journal of Economics. 1992; 107:35-78.

35. Korenman S, Neumark D. Cohort crowding and youth labor markets: a cross-sectional analysis. In: Blanchflower D, Freeman R, editors. Youth Employment and Joblessness in Advanced Countries. Chicago: NBER Chicago University Press; 2000. p. 57-105.

36. Sapozhnikov M, Triest RK. Population aging, labor demand, and the structure of wages. Work Opportunities for Older Americans Series Working Paper. 2007; 8.

37. Shimer R. The impact of young workers on the aggregate labor market. The Quarterly Journal of Economics. 2001; 116:969-1007.

38. Skans ON. Age effects in Swedish local labor markets. Economics Letters. 2005; 86:419-26.

39. Welch F. Effects of cohort size on earnings: the baby boom babies' financial bust. The Journal of Political Economy. 1979; 87:S65-S97.

40. Mincer J. Schooling, Experience, and Earnings. New York: National Bureau of Economic Research (NBER); 1974.

41. Borjas GJ. The labor demand curve is downward sloping: Reexamining the impact of immigration on the labor market. Quarterly Journal of Economics. 2003; 118.

42. Martins PS, Pereira PT. Does education reduce wage inequality? Quantile regression evidence from 16 countries. Labour Economics. 2004; 11:355-71.

43. Despa S. Quantile Regression. Cornell University, Cornell Statistical Consulting, StatNews. 2007; 70.

44. Becker GS. Nobel lecture: The economic way of looking at behavior. Journal of Political Economy. 1993; 101:385-409.

45. Acemoglu DA. Microfundation for social increasing returns in human capital. Quartely Journal of Economics. 1996; 111:779-804. 